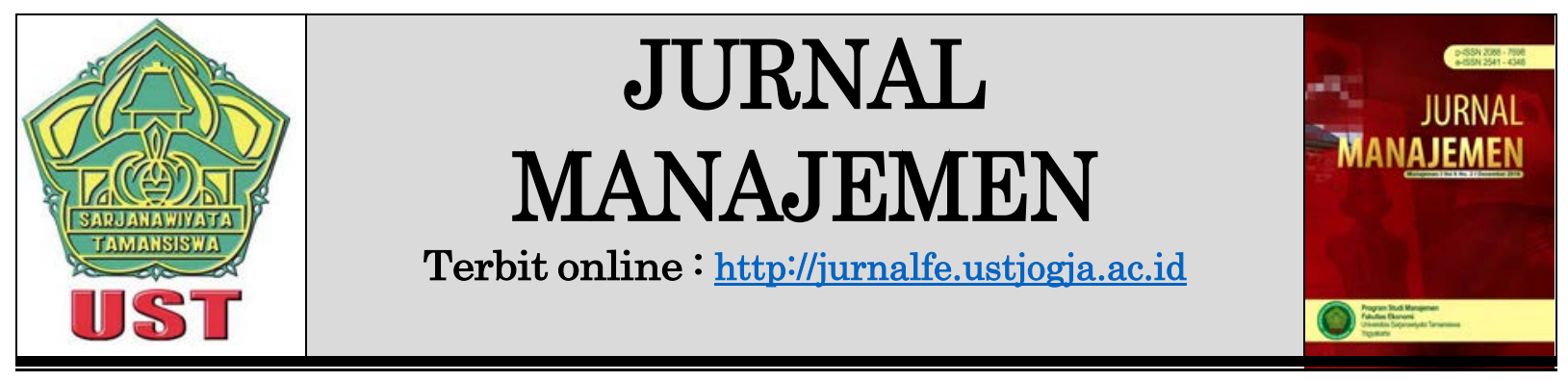

\title{
PENGARUH KUALITAS PESAN IKLAN SMARTPHONE SAMSUNG TERHADAP NIAT BELI DENGAN CITRA MEREK SEBAGAI VARIABEL PEMEDIASI
}

\section{Chriswardana Bayu Dewa}

Universitas BSI

Korespondensi: chriswardana.chb@bsi.ac.id

\begin{tabular}{ll}
\hline Informasi Naskah & Abstrak \\
\hline Diterima: & This research aims to examine the effect of quality of the \\
27 September & advertising message to the buying intention and mediated by \\
Revisi: & brand image. Subjects are people who use Samsung mobile in \\
11 Oktober & Yogyakarta. In this study developed a theoretical mode of the \\
Terbit: & proposed four hypotheses to be tested using Structural \\
16 Desember & Equation Model SEM) by AMOS software 18. This research \\
Kata Kunci: & was conducted by distributing questionnaires to survey 150 \\
Quality of advertising & respondents. Respondents were obtained through purposive \\
message, samsung & sampling tehnique, the respondents were selected based on \\
mobile, purchase & certain goals established researcher. The results of this study \\
intention & show that quality of the advertising message has positive effect \\
& to brand image, brand image has positive effect to buying \\
& intention, quality of the advertising message has positive effect \\
& to buying intention and brand image can partially mediated the \\
& positive effect of quality of advertising message toward buying \\
& intention.
\end{tabular}

\section{PENDAHULUAN}

Media sosial merupakan hasil integrasi antara wadah media dengan komunikasi sosial. Media sosial menjadi salah satu perangkat di dalam dunia maya yang memberikan fasilitas komunikasi dan interaksi antara para user di dunia maya. Saat ini pertumbuhan pengguna media sosial sangat pesat sehingga banyak perusahaan menggunakan pemasaran melalui media sosial, karena pemasaran melalui media sosial dianggap sebagai salah satu strategi yang efektif untuk membangun interaksi atau hubungan dengan konsumen. Mereka menggunakan media sosial sebagai sarana jaringan untuk meraih minat konsumen.

Media sosial mengarah kepada hubungan antara manusia, untuk saling berbagi pesan dan bertukar informasi dalam komunitas virtual dan dalam berbagai jaringan. 
Media sosial adalah kelompok aplikasi berbasis internet yang dibangun berdasarkan ideologi dan teknologi web 2.0, agar memungkinkan kreasi dan pertukaran informasi para penggunanya (Fazli et al, 2010). Media sosial tergantung pada teknologi mobile dan berbasis web untuk membuat landasan interaksi yang tinggi antar individu dan komunitas. Media sosial memberikan komunikasi yang kokoh antar individu, komunitas dan organisasi.

Membuat iklan pada media sosial merupakan peluang bagi perusahaan untuk mencapai tujuannya. Situs jejaring sosial dan media sosial lainnya menunjukkan lebih dari ratusan juta percakapan, 72 jam durasi video diunggah setiap menitnya, jutaan blog tiap hari, jutaan tweet tiap hari, sehingga memberikan peluang yang besar bagi perusahaan dalam menempatkan iklan untuk berkomunikasi dengan konsumennya. Perusahaan perlu memiliki strategi yang kreatif agar konsumen menjadi loyal dan merasa menjadi bagian dari produk yang dihasilkan oleh perusahaan tersebut.

Perubahan lingkungan yang cepat dan terciptanya produk-produk inovatif membuat perusahaan harus mampu bertahan dan bersaing dalam perkembangan lingkungan bisnis. Demikian juga dengan pasar smartphone. Ilmu pengetahuan dan teknologi berkembang sangat pesat dalam pasar smartphone, sehingga masyarakat terdorong untuk mengikuti dan menggunakan pengembangan teknologi tersebut. Terdapat banyak merek smartphone di Indonesia. Tapi, hanya 2 merek smartphone yang paling diminati, yaitu Iphone dan Samsung. Berdasarkan data dari www.teknojournal.com pada bulan Januari 2016, merek smartphone yang paling dicari adalah Samsung dengan presentase 53\% disusul oleh Iphone 32\% dan sisanya merek lain.

Peningkatan pengguna smartphone di Indonesia akan terus terjadi di beberapa waktu ke depan. Merek smartphone Samsung menjadi pilihan dalam penelitian ini karena merek smartphone ini paling diminati di Indonesia pada tahun 2015. Dalam www.detiknet.com produsen Samsung mengklaim ponsel cerdasnya sangat laris di Indonesia dengan pertumbuhan 49,4\% pada tahun 2012. Berdasarkan laporan Growth from knowledege (GFK) bulan Juli 2014, penjualan Samsung masih nomor satu. Lebih dari separuh $(53,6 \%)$ penjualan smartphone tertinggi adalah Samsung.

Menurut artikel Trading Myths McKinsey Global Institute, terdapat lebih dari 10.000 gerai mobile phone di Indonesia menjual produk Samsung, dimana mereka telah memberikan kontribusi yang cukup besar bagi Indonesia dengan menciptakan 12.000 lapangan pekerjaan untuk penjualan dan layanan purna jual. Layanan penjualan Samsung di Indonesia berbeda dengan negara lain, karena Samsung dapat memberikan garansi selama 24 bulan untuk semua jenis produk Smartphone Samsung yang dibeli dari gerai resmi. Menurut data dari www.tabloidpulsa.com pasar Samsung di Indonesia bertumbuh dengan cepat dan diperkirakan akan mencapai 9,7 juta orang pada tahun 2016. Pertumbuhan ini sangat tinggi ditengah maraknya persaingan pasar smartphone di Indonesia. Banyak produk pesaing dari berbagai merek yang memiliki fitur yang sama dengan harga lebih murah, seperti Oppo, Asus, Xiaomi, dan lainnya, tetapi tidak memiliki penjualan yang tinggi seperti produk Samsung. Hal ini memberikan fenomena baru bahwa persaingan perusahaan untuk merebut konsumen tidak hanya dibatasi oleh atribut fungsional saja tapi juga dikaitkan dengan merek yang memberikan citra khusus bagi para pemakainya.

Peranan merek telah mengalami evolusi (Aaker, 2000). Pada tingkat persaingan yang rendah, merek hanya sekedar nama, sedangkan pada tingkat persaingan yang tinggi merek memberikan kontribusi dalam menciptakan kekuatan sebuah produk. Merek memiliki peranan untuk memberikan kesan positif atau negatif pada benak konsumen. Menurut Lassar et al (2008), merek memiliki lima dimensi yaitu kinerja 
(performance),citra soisal (social image), nilai (value,) kepercayaan (trustwothiness) dan komitmen (commitment). Dimensi-dimensi ini yang menjadikan perusahaan semakin menyadari bahwa merek adalah aset perusahaan yang bernilai tinggi. Keagen et al(2005) mengatakan bahwa merek merupakan janji perusahaan yang secara konsisten memberikan ciri khas, keuntungan dan pelayanan kepada pelanggan. Karena "janji” ini yang membuat konsumen mengenal merek tersebut lebih dari yang lain.

Menurut www.liputan6.com, persaingan perusahaan dewasa ini tidak hanya terjadi pada segi merek produk saja, tetapi juga ditekankan pada fungsi, fitur, harga, kemasan, pelayanan, iklan dan lain-lain yang disesuaikan pada kebutuhan konsumen. Perusahaan-perusahaan dalam memenangkan persaingan melakukan investasi yang besar pada iklan (Mudianto dan Purnomo, 2005). Banyak perusahaan melakukan investasi yang besar pada iklan karena iklan adalah alat yang efektif dalam memelihara loyalitas merek. Murdianto dan Purnomo (2005) juga mengatakan bahwa iklan digunakan perusahaan untuk mempertahankan informasi kegunaan produk. Konsumen dapat memberikan pendapat yang positif atau negatif terhadap produk melalui iklan (Wells, 2013). Iklan dapat membuat daya tarik konsumen terhadap produk (Stanton, 2004). Daya tarik memiliki fungsi untuk memberikan gambaran kualitas yang baik pada produk, sehingga mendorong konsumen untuk menentukan keputusan akhir dari produk yang terdapat di pasar.

Yoestini et al (2007) mengatakan bahwa konsumen bersedia untuk membeli suatu produk apabila produk tersebut sesuai dengan ekspetasi konsumen saat produk tersebut dikonsumsi. Konsumen rela mengeluarkan uang jika produk tersebut dapat memenuhi kebutuhan dan harapannya. Iklan memberikan pengetahuan tentang produk kepada konsumen, sehingga kepercayaan atau pengetahuan konsumen tentang produk dapat mempengaruhi sikap dan tindakan konsumen untuk membeli atau tidak membeli. Minat beli adalah rencana konatif konsumen untuk membeli barang atau merek tertentu (Kinnear dan Taylor, 2005). Minat beli memberikan dorongan bagi konsumen untuk melakukan pertimbangan pembelian, sebelum pembelian benar-benar dilakukan. Merek yang dikenal oleh konsumen akan menimbulkan minat untuk mengambil keputusan pembelian. Dengan berkembangnya teknologi, perusahaan menggunakan media sosial sebagai alat untuk mengiklankan produknya dengan tujuan meningkatkan citra merek produk, sehingga menimbulkan minat beli konsumen.

Perumusan masalah mengacu pada apakah kualitas pesan iklan nedia sosial berpengaruh positif terhadap citra merek, apakah citra merek berpengaruh positif terhadap niat beli, apakah kualitas pesan iklan media sosial berpengaruh positif terhadap niat beli dan apakah citra merek memediasi pengaruh antara kualitas pesan iklan media sosial terhadap niat beli. Secara umum penelitian ini bertujuan untuk menguji signifikansi pengaruh antara kualitas pesan iklan media sosial terhadap niat beli melalui citra merek. Secara khusus penelitian ini bertujuan memperoleh hasil analisis peran antar variabel yaitu besaran peran kualitas pesan iklan media sosial terhadap citra merek, dan niat beli, serta besaran pesan antara citra merek terhadap niat beli.

\section{KAJIAN PUSTAKA DAN HIPOTESIS}

Russel dan Lane (2006) mengatakan bahwa iklan yang sukses adalah iklan yang didefinisikan oleh banyak orang sebagai iklan yang memberikan isu yang positif. Ciri konsumsi konsumen pada masa lalu tidak mementingkan produk yang bermerek, tetapi konsumsi lebih banyak pada barang-barang komoditas seperti tepung, garam, dan gula dalam jumlah yang besar. Akan tetapi, di masa modern saat ini merek mulai diperkenalkan melalui iklan dengan menjamin kualitas dan pembeda bagi produk yang 
dijual oleh produsen.

Iklan produk terdiri dari tiga fase yaitu perintisan, pembanding dan pengingat. Periklanan memiliki pengaruh yang kuat secara persuasif, mampu memperkenalkan produk baru atau kegunaan baru, mampu membantu konsumen untuk membedakan produk suatu merek dengan produk merek lain, dan mampu mendemonstrasikan cara penggunaan produk ( Stanton, et al 2004). Iklan dikatakan efektif apabila dapat menjelaskan bahwa produk yang diiklankan lebih baik daripada produk pesaing dalam waktu yang tidak terlalu panjang. Bendixen (2003) mengatakan bahawa iklan memiliki tujuan yaitu, menciptakan pengenalan produk atau merek baru, memberi informasi kepada konsumen tentang keunggulan produk atau merek, menciptakan persepsi yang baik terhadap produk atau merek, menciptakan pilihan atas produk atau merek, dan membujuk konsumen untuk membeli produk atau merek. Seluruh tujuan iklan ini digunakan untuk meningkatkan respon konsumen kepada perusahaan sehingga memberikan keuntungan penjualan dalam jangka panjang.

Russel dan Lane (2006) mengatakan keberhasilan iklan diukur dari produk yang baik, waktu yang tepat, diferensiasi produk dan kompetisi harga. Kesuksesan iklan produk terjadi ketika produk dibutuhkan oleh konsumen, harga bersaing, kualitas bagus dan tidak ada barang pengganti. Melalui iklan, orang dapat mempunyai opini yang menyenangkan atau yang tidak menyenangkan terhadap produk yang diiklankan. Selain itu iklan juga mampu menciptakan daya tarik yang dapat membuat produk yang diiklankan menjadi menarik bagi konsumen.Daya tarik digunakan untuk menciptakan kualitas produk yang mahal (Wells et al, 2013). Setiap iklan yang ditayangkan selalu memiliki unsur komunikasi. Pemasar menggunakan komunikasi tersebut untuk menanamkan persepsi positif produk ke dalam benak konsumen, agar melakukan kegiatan sesuai dengan kehendak pemasar, yaitu sampai pada tahap pembelian.

Iklan adalah salah satu cara pembentukan ekuitas merek serta memberi pemahaman atau pengetahuan merek kepada konsumen dan memungkinkan merek untuk melekat ke dalam benak konsumen yang akan memberi kontribusi dalam pembentukan citra merek (Khrishan dan Chakravati, 2003). Citra merek dapat terbentuk oleh pengaruh pesan iklan sebuah produk. Iklan berperan penting dalam penguatan terhadap sikap dan keyakinan konsumen tentang merek yang ditawarkan (Rahaja, 2011). Iklan dengan pesan yang berkualitas dapat menghasilkan sikap konsumen yang positif terhadap produk (Sukarno, 2005). Iklan yang memiliki pesan yang berkualitas akan membuat konsumen menjadi tahu atau kenal dengan merek produk yang diiklankan. Iklan yang memiliki pesan yang berkualitas diharapkan mampu menyampaikan pesan yang dapat menambah pengetahuan tentang merek produk kepada konsumen.

Merek adalah sebuah nama, istilah, tanda, simbol, rancangan atau kombinasinya yang dimaksudkan untuk mengenali produk atau jasa dan untuk membedakan dari produk pesaing (Kotler 2013). Merek juga dapat dikatakan sebagai janji, kepercayaan dan pengharapan sehingga merek dari produk yang kuat akan menjadikan konsumen memiliki keyakinan, kenyamanan dan keamanan yang tinggi ketika membeli produk tersebut (Durianto et al, 2001). Merek adalah entitas yang mudah dikenali dan menjanjikan nilai-nilai tertentu (Nocilino, 2014). Merek merupakan nilai berwujud dan tidak berwujud yang terwakili dalam sebuah trademark sehingga mampu menciptakan nilai dan pengaruh tersendiri di pasar. Saat ini merek sudah menjadi konsep yang komplek dengan sejumlah ratifikasi teknis dan psikologis.

Citra merek adalah persepsi rasional dan emosional suatu merek (Dobni dan Zinken 2010). Persaingan perusahaan untuk memperebutkan konsumen tidak lagi terbatas pada atribut fungsional produk seperti kegunaan produk melainkan sudah 
dikaitkan dengan merek yang mampu memberi citra khusus bagi pemakainya, dengan kata lain peranan merek mengalami pergeseran (Aaker, 2011). Menurut Hoeffler dan Keller (2013) dimensi citra merek terdiri atas

a. Atribut produk yaitu manfaat dan perilaku secara umum, terkait kualitas dan inovasi

b. Orang dan relationship, terkait pada konsumen (customer orientation)

c. Nilai dan program, terkait kepedulian lingkungan dan tanggung jawab sosial.

d. Kredibilitas perusahaan, terkait keahlian dan kepercayaan.

Semakin kuat citra merek suatu produk, semakin kuat pula niat konsumen untuk mengkonsumsi produk tersebut. Perusahaan dengan citra merek yang kuat seharusnya memiliki kualitas kerja yang baik (Shih, 2010). Citra merek yang kuat memberikan gambaran finansial perusahaan dalam kondisi optimal, sehingga memberikan impresi kepada konsumen bahwa produk yang dihasilkan memiliki kualitas yang baik dan dapat menjamin kepuasan konsumen. Niat beli adalah prediksi tentang tindakan-tindakan konsumen yang menimbulkan keputusan pembelian pada masa yang akan datang. Variabel seperti mempertimbangkan, mengharapkan dan merekomendasikan untuk membeli sebuah merek suatu produk menjadi pengukuran dari niat beli (Shih, 2010). Niat beli membantu untuk memprediksi kelanjutan pembelian atau pembelian ulang. Informasi tentang niat beli akan terlihat secara detail dari skala niat beli yang dirancang untuk menimbulkan respon konsumen pada pertanyaan tentang produk yang dibeli pada periode waktu tertentu (Tirtiroglu dan Elbeck, 2008).

Menurut Aaker (2010), niat beli memiliki beberapa indikator, yaitu :

a. Preferensi produk

Merek suatu produk lebih dipilih untuk dibeli dibandingkan merek produk lain.

b. Pembelian di masa yang akan datang

Memiliki minat atau keinginan untuk membeli produk di masa yang akan datang.

c. Loyalitas

Komitmen konsumen yang kuat sehingga dapat menciptakan niat untuk membeli suatu produk.

Peran kualitas pesan iklan terhadap minat beli dapat terlihat dari keputusankeputusan pembelian konsumen terhadap suatu produk (Sukarno, 2005). Kualitas pesan iklan pada media sosial akan mempengaruhi persepsi konsumen tentang suatu merek dan mempengaruhi evaluasi mereka akan merek tersebut. Jika konsumen memilik persepsi positif (negatif) terhadap kualitas pesan iklan suatu produk, persepsi tersebut akan mengarahkan kepada evaluasi positif (negatif) terhadap citra merek yang terdapat dalam iklan tersebut. Semakin kuat citra merek dalam sebuah iklan maka semakin kuat pula niat konsumen untuk membeli produk tersebut.

Hipotesis dalam penelitian ini adalah :

H1 : Kualitas pesan iklan berpengaruh positif terhadap citra merek.

H2 : Citra merek berpengaruh positif terhadap minat beli

H3 : Kualitas pesan iklan media sosial berpengaruh positif terhadap minat beli.

H4 : Citra merek memediasi pengaruh kualitas pesan iklan terhadap minat beli. 


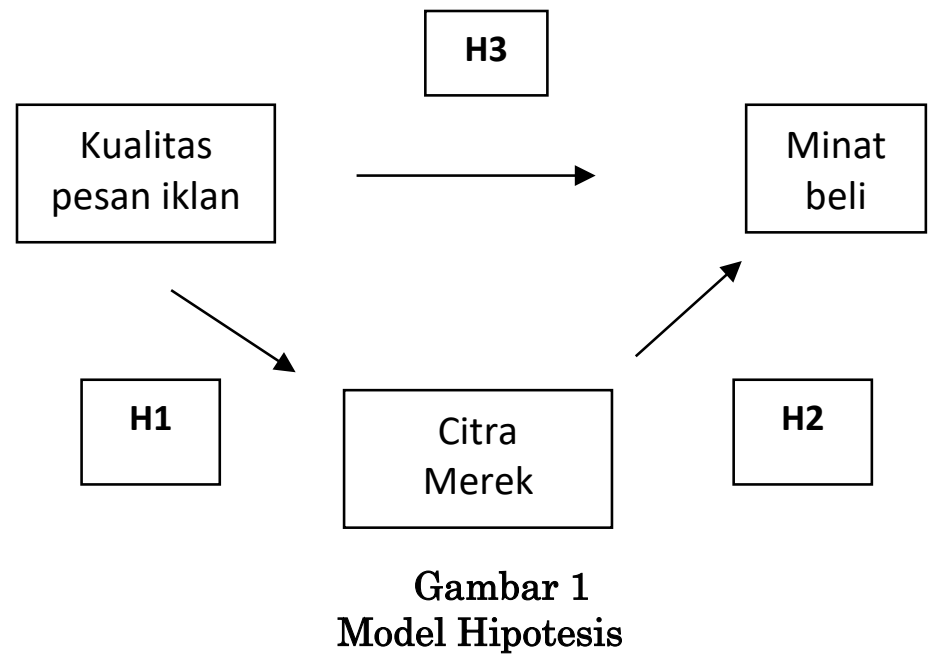

\section{METODE PENELITIAN}

Populasi dalam penelitian ini adalah pengguna smartphone Samsung yang ada di Yogyakarta. Dari populasi tersebut peneliti menentukan sampel. Tehnik penentuan sampel yang dilakukan adalah teknik purposive sampling. Teknik penentuan sampel ini ditentukan berdasarkan ciri tertentu yang dianggap mempunyai hubungan erat dengan ciri populasi. Purposive sampling secara spesifik disebut juga judgement sampling yaitu metode yang sengaja digunakan karena informasi yang diambil berasal dari sumber yang dipilih berdasarkan kriteria tertentu. Kriteria yang digunakan dalam sampel penelitian ini adalah konsumen yang memiliki dan menggunakan smartphone merek Samsung dan bertempat tinggal di Yogyakarta. Jenis data yang digunakan adalah data kuantitatif dan sumber data yang digunakan adalah data primer. Pengumpulan data dalam penelitian ini dilakukan dengan metode survei, yaitu pengumpulan data dengan menggunakan pertanyaan atau kuesioner yang dibagikan langsung kepada responden untuk ditanggapi dan diisi, kemudian diserahkan kembali secara langsung kepada peneliti dengan tujuan meningkatkan jumlah pengembalian kuesioner. Penyebaran kuesioner dilakukan secara online melalui alamat email atau pesan media sosial facebook kepada grup pengguna produk smartphone Samsung di kota Yogyakarta. Responden yang mengirim kembali kuesioner berjumlah 150 orang.

Definisi operasional kualitas pesan iklan adalah nilai komunikasi perusahaan dalam menyampaikan pengetahuan dan pemahaman tentang merek kepada konsumen dan memungkinkan merek tersebut melekat di benak konsumen yang akan memberikan kontribusi dalam pembentukan asosiasi merek (Khrishan dan Chakravati, 2003). Untuk mengukur kualitas pesan iklan peneliti menggunakan kuesioner dengan salah satu contoh pernyataan adalah "Saya sangat mudah memahami pesan iklan smartphone merek Samsung”. Pengukuran menggunakan skala Likert dari skala 1 hingga 5.

Definisi operasional citra merek adalah persepsi rasional dan emosional suat merek (Low dan Lamb,2010). Merek akan dihubungkan dengan citra khusus yang mampu memberi asosiasi tertentu di benak konsumen. Menurut Hoeffler dan Keller (2013), terdapat beberapa indikator variabel citra merek, yaitu kesan profesional, kesan modern, melayani semua segmen, dan peduli kebutuhan konsumen. Untuk mengukur variabel citra merek, peneliti menggunakan kuesioner dengan salah satu contoh pernyataan adalah "Saat ini smartphone merek Samsung dikenal sebagai smartphone yang mampu memberikan kebutuhan komunikasi secara profesional". Pengukuran menggunakan 
skala Likert dari skala 1 hingga 5.

Definisi operasional minat beli adalah preferensi pada produk tertentu dibandingkan produk yang lain, membeli produk pada saat dibutuhkan dan tidak membeli produk yang lain ketika produk tersebut tidak ada di pasar (Tseng et al, 2012). Variabelvariabel seperti mempertimbangkan, mengharapkan dan merekomendasikan untuk membeli sebuah merek suatu produk menjadi pengukuran minat beli (Shih, 2010). Minat beli membantu untuk memprediksi kelanjutan pembelian atau pembelian ulang. Informasi tentang minat beli akan terlihat secara detail dari skala minat beli yang dirancang untuk menimbulkan respon konsumen pada pertanyaan tentang produk yang dibeli pada periode waktu tertentu (Tirtiroglu dan Elbeck, 2008). Untuk mengukur variabel minat beli, peneliti menggunakan kuesioner dengan salah satu contoh pernyataan adalah "Saya akan membeli smartphone merek Samsung daripada smartphone merek lain". Pengukuran menggunakan skala Likert dari skala 1 hingga 5.

Dalam penelitian ini, validitas akan diuji menggunakan alat ukur analisis faktor yang diperoleh dengan alat bantu program SPSS 16. Uji reliabilitas dilakukan dengan menghitung cronbach's alpha menggunakan SPSS 16 sebagai alat uji. Nilai cronbach's alpha dikategorikan sebagai berikut : 1) 0,8-1,0: reliabilitas baik, 2) 0,6-7,9: reliabilitas diterima, 3) <0,6: reliabilitas buruk. Pengujian hipotesis dilakukan dengan menggunakan SEM dengan bantuan program AMOS 16.0. Pengujian hipotesis dari H1, H2, H3, diuji dengan melihat significant path pada penelitian, sedangkan untuk $\mathrm{H} 4$ diuji dengan membandingkan nilai beta pengaruh kualitas pesan iklan media sosial terhadap niat beli pada model penelitian (gambar 1) dengan model alternatif (gambar 2). Model alternatif dalam penelitian ini adalah pengaruh langsung antara kualitas pesan iklan media sosial terhadap niat beli tanpa mediasi, sedangkan model penelitian adalah pengaruh kualitas pesan iklan media sosial terhadap minat beli melalui citra merek sebagai mediasi.

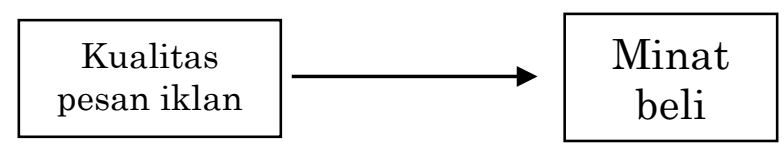

Gambar 2. Model Alternatif

Jika pada model alternatif terdapat beta yang signifikan sedangkan pada model penelitian tidak ada nilai beta yang signifikan maka medias sempurna (full mediation), tapi jika pada model alternatif terdapat nilai beta yang signifikan sedangkan pada model penelitian terdapat nilai beta signifikan tetapi nilainya lebih kecil dari model alternatif maka mediasi parsial (partial mediation).

\section{HASIL DAN PEMBAHASAN}

Hasil pengujian validitas ditemukan bahwa setiap item pertanyaan untuk setiap variabel valid, sehingga dapat digunakan dalam pengujian hipotesis.

Tabel 1

Hasil Uji Validitas Variabel Kualitas Pesan Iklan

\begin{tabular}{clcc}
\hline Kode & \multicolumn{1}{c}{ Item Pernyataan } & $\begin{array}{c}\text { Faktor } \\
\text { Loading }\end{array}$ & Status \\
\hline KI1 & $\begin{array}{l}\text { Saya sangat mudah memahami pesan iklan } \\
\text { smartphone merek Samsung di media sosial. }\end{array}$ & 0,812 & Valid \\
KI2 & $\begin{array}{l}\text { Saya mengingat pesan iklan smartphone merek } \\
\text { Samsung di media sosial. }\end{array}$ & 0,854 & Valid \\
KI3 & Iklan smartphone merek Samsung di media sosial & 0,856 & Valid \\
\hline
\end{tabular}


memberikan informasi yang sangat saya percaya

KI4 Iklan smartphone merek Samsung di media sosial

$0,840 \quad$ Valid memberi informasi yang saya butuhkan secara jelas.

Tabel 2

Hasil Uji Validitas Variabel Citra Merek

\begin{tabular}{clcc}
\hline Kode & \multicolumn{1}{c}{ Item Pernyataan } & $\begin{array}{c}\text { Faktor } \\
\text { Loading }\end{array}$ & Status \\
\hline CM1 & $\begin{array}{l}\text { Saat ini smartphone merek Samsung dikenal sebagai } \\
\text { smartphone yang mampu memberikan kebutuhan } \\
\text { komunikasi secara profesional. }\end{array}$ & 0,929 & Valid \\
CM2 & $\begin{array}{l}\text { Saat ini smartphone merek Samsung memiliki } \\
\text { dukungan teknologi yang paling modern. }\end{array}$ & 0,908 & Valid \\
CM3 & $\begin{array}{l}\text { Saat ini smartphone merek Samsung dikenal sebagai } \\
\text { smartphone yang melayani semua segmen pasar } \\
\text { (harga terjangkau) }\end{array}$ & 0,877 & Valid \\
CM4 & $\begin{array}{l}\text { Saat ini smartphone merek Samsung dikenal sebagai } \\
\text { smartphone yang mampu memenuhi kebutuhan } \\
\text { komunikasi konsumen. }\end{array}$ & 0,840 & Valid \\
\hline
\end{tabular}

Tabel 3

Hasil Uji Validitas Variabel Minat Beli

\begin{tabular}{|c|c|c|c|}
\hline Kode & Item Pernyataan & Faktor Loading & Status \\
\hline MB1 & $\begin{array}{l}\text { Saya akan membeli } \\
\text { smartphone merek Samsung } \\
\text { daripada smartphone merek } \\
\text { lain. }\end{array}$ & 0,894 & Valid \\
\hline MB2 & $\begin{array}{l}\text { Saya akan membeli } \\
\text { smartphone merek Samsung } \\
\text { di masa yang akan datang. }\end{array}$ & 0,917 & Valid \\
\hline MB3 & $\begin{array}{l}\text { Saat ini saya sudah memiliki } \\
\text { smartphone merek Samsung. } \\
\text { Jika saya akan membeli } \\
\text { smartphone lagi, saya tetap } \\
\text { membeli smartphone merek } \\
\text { Samsung. }\end{array}$ & 0,894 & Valid \\
\hline MB4 & $\begin{array}{l}\text { Saya akan memberi informasi } \\
\text { kepada orang lain dan } \\
\text { menyarankan untuk membeli } \\
\text { smartphone merek Samsung. }\end{array}$ & 0,813 & Valid \\
\hline
\end{tabular}

Setelah melakukan uji validitas, data pada item pertanyaan yang valid diuji reliabilitasnya menggunakan metode cronbach's alpha. Berdasarkan pengujian didapat bahwa variabel kualitas pesan iklan, citra merek dan minat beli adalah reliabel. Hasil output uji reliabilitas untuk variabel kualitas pesan iklan, citra merek dan minat beli dapat diringkas pada table 4 
Tabel 4

Hasil Uji Reliabilitas

\begin{tabular}{ccc}
\hline Variabel & Cronbach alpha & Kategori \\
\hline $\begin{array}{c}\text { Kualitas pesan } \\
\text { iklan }\end{array}$ & 0,861 & Reliabilitas baik \\
Citra merek & 0,907 & Reliabilitas baik \\
Minat beli & 0,903 & Reliabilitas baik \\
\hline
\end{tabular}

Sebelum melakukan pengujian hipotesis, peneliti melakukan pengujian model fit, yang bertujuan untuk menentukan kesesuaian model dengan data. Pada penelitian ini nilai-nilai absolute fit menunjukkan bahwa secara umum model mempunyai goodnes of fit yang cukup baik, sehingga pengujian hipotesis dapat dilakukan dengan model yang ada. Berikut hasil dari model fit dalam penelitian ini.

Tabel 5

Hasil Pengujian Model Fit

\begin{tabular}{cccc}
\hline Goodness-of-fit Index & Kriteria & $\begin{array}{c}\text { Hasil Olah } \\
\text { Data }\end{array}$ & Evaluasi Model \\
\hline Chi Square & Tidak signifikan & 150 & Kurang baik \\
CMIN/DF & $1-2$ over fit, $2-5$ liberal & 1,195 & Baik \\
& limit & & \\
GFI & $>0,90$ & 0,874 & Cukup \\
AGFI & $>0,80$ & 0,830 & Baik \\
TLI & $>0,9$ & 0,983 & Baik \\
CFI & $>0,9$ & 0,986 & Baik \\
RMSEA & $<0,08$ upper limit $<$ & 0,041 & Baik \\
& 0,1 & & \\
\hline
\end{tabular}

Nilai GFI (Goodnes of Fit) sebesar 0,874. Nilai GFI yang baik adalah yang mendekati angka 1, jadi nilai kesesuaian model dengan data dalam penelitian ini dapat dikatakan cukup. Nilai RMSEA sebesar 0,041 dapat memenuhi kriteria penerimaan model karena tidak melebihi batas atas 0,1 .

Nilai CFI (Comparative Fit Index) sebesar 0,986 memenuhi batas minimum 0,9. Nilai AGFI (Adjusted Goodnes Fit) sebesar 0,830 memenuhi batas minimum 0,8. Nilai CMIN/DF masih diatas standar, yaitu 1,195, dengan nilai batas maksimal adalah 5 . Hasil ini menunjukkan bahwa model memiliki unsur parsimoni. Berdasarkan nilai-nilai tersebut dapat disimpulkan bahwa secara umum nilai-nilai incremental fit menunjukkan hasil yang baik.

Pengujian hipotesis dari $\mathrm{H} 1, \mathrm{H} 2, \mathrm{H} 3$, diuji dengan melihat significant path pada penelitian, sedangkan untuk $\mathrm{H} 4$ diuji dengan membandingkan nilai beta pengaruh kualitas pesan iklan terhadap minat beli. Hasil pengujian hipotesis dapat terlihat pada tabel 6.

Tabel 6

Hasil Uji Hipotesis 


\begin{tabular}{|c|c|c|c|c|}
\hline No. & Isi Hipotesis & $\begin{array}{c}\text { Standardized } \\
\text { Regression Weights }\end{array}$ & $\mathbf{P}$ & Keterangan \\
\hline $\mathrm{H} 1$ & $\begin{array}{l}\text { Kualitas pesan } \\
\text { iklan berpengaruh } \\
\text { positif terhadap } \\
\text { citra merek }\end{array}$ & 0,328 & $<0,01$ & Hipotesis diterima \\
\hline $\mathrm{H} 2$ & $\begin{array}{l}\text { Citra merek } \\
\text { berpengaruh positif } \\
\text { terhadap minat beli }\end{array}$ & 0,476 & $<0,01$ & Hipotesis diterima \\
\hline H3 & $\begin{array}{l}\text { Kualitas pesan } \\
\text { iklan berperngaruh } \\
\text { positif terhadap } \\
\text { minat beli }\end{array}$ & 0,378 & 0,028 & Hipotesis diterima \\
\hline \multicolumn{5}{|c|}{$\begin{array}{c}\text { Tabel } 7 \\
\text { Hasil Pembanding Mediasi }\end{array}$} \\
\hline No. & Isi Hipotesis & $\begin{array}{c}\text { Standardized } \\
\text { Regression Weights }\end{array}$ & $\mathbf{P}$ & Keterangan \\
\hline $\mathrm{H} 3 \mathrm{a}$ & $\begin{array}{l}\text { Kualitas pesan } \\
\text { iklan berpengaruh } \\
\text { positif terhadap } \\
\text { minat beli yang } \\
\text { dimediasi citra } \\
\text { merek }\end{array}$ & 0,378 & 0,028 & Hipotesis diterima \\
\hline $\mathrm{H} 3 \mathrm{~b}$ & $\begin{array}{l}\text { Kualitas pesan } \\
\text { iklan berpengaruh } \\
\text { positif terhadap } \\
\text { minat beli }\end{array}$ & 0,589 & $<0,01$ & Hipotesis diterima \\
\hline
\end{tabular}

Pada tabel 6 ditemukan bahwa kualitas pesan iklan berpengaruh positif terhadap citra merek $(B=0,328, P<0,05)$. Hasil analisis ini mendukung hipotesis pertama peneliti. Jadi, dapat diartikan bahwa, semakin baik kualitas pesan iklan, maka membawa dampak citra merek semakin tinggi. Menurut Khrishan dan Chakravati (2003), Iklan adalah salah satu cara pembentukan ekuitas merek serta memberi pemahaman atau pengetahuan merek kepada konsumen dan memungkinkan merek untuk melekat ke dalam benak konsumen yang akan memberi kontribusi dalam pembentukan citra merek.

Citra merek berpengaruh positif terhadap minat beli $(B=0,476, \mathrm{P}<0,05)$. Hasil analisis ini mendukung hipotesis kedua peneliti. Jadi, semakin tinggi citra merek maka membawa dampak semakin tinggi minat beli konsumen. Penelitian ini mendukung pernyataan dari Shih (2010) yaitu semakin kuat citra merek suatu produk, semakin kuat pula niat konsumen untuk mengkonsumsi produk tersebut dan perusahaan dengan citra merek yang kuat mengindikasikan kualitas kerja yang baik.

Kualitas pesan iklan berpengaruh positif terhadap minat beli $(B=0,378, \mathrm{P}<0,05)$. Hasil ini mendukung hipotesis ketiga peneliti. Jadi, semakin tinggi kualitas pesan iklan di media sosial membawa dampak semakin tinggi minat beli konsumen. Menurut Sukarno (2005), peran kualitas pesan iklan terhadap minat beli dapat terlihat dari keputusankeputusan pembelian konsumen terhadap suatu produk. Semakin baik kualitas pesan iklan maka semakin mendorong minat konsumen untuk membeli produk tersebut. 
Hasil analisis pada tabel 7 menunjukkan bahwa citra merek memediasi hubungan antara kualitas pesan iklan dengan minat beli $(B=0,378, \mathrm{P}<0,05)$, sedangkan hubungan antara kualitas pesan iklan dengan minat beli tanpa mediasi memiliki $B=0,589 ; \mathrm{P}<0,05$. Hal ini berarti citra merek memediasi hubungan antara kualitas pesan iklan terhadap minat beli secara parsial karena nilai beta model penelitian lebih kecil dibandingkan dengan nilai beta model alternatif. Jadi, hubungan yang signifikan bukan hanya terjadi antara citra merek sebagai variabel mediator terhadap minat sebagai variabel dependen, tetapi juga hubungan langsung antara kualitas pesan iklan sebagai variabel independen terhadap minat beli sebagai variabel dependen. Selain itu, ekuitas merek berarti mampu menjadi penghubung pengaruh positif antara kualitas pesan iklan dengan minat beli. Semakin tinggi kualitas pesan iklan berarti semakin tinggi pula citra merek sehingga meningkatkan minat beli konsumen.

\section{PENUTUP}

Dari hasil pembahasan dapat disimpulkan bahwa kualitas pesan iklan dapat mempengaruhi citra merek secara positif artinya kualitas pesan iklan dapat mempengaruhi pandangan konsumen terhadap citra merek. Jika pesan iklan yang diberikan positif maka akan meningkatkan citra merek, sedangkan jika pesan iklan yang diberikan adalah negatif maka akan menurunkan citra merek sebuah produk. Smartphone merek Samsung merupakan merek yang familiar digunakan oleh masyarakat di kota Yogyakarta. Hal ini tidak terlepas dari peran pesan iklan yang terdapat diberbagai media terutama media sosial. Kualitas pesan iklan smartphone Samsung yang positif di media sosial mampu meningkatkan citra merek produk tersebut. Dengan kualitas pesan iklan smartphone Samsung yang positif maka meningkatkan pandangan konsumen terhadap merek tersebut, sehingga dapat disimpulkan bahwa kualitas pesan iklan yang positif mampu meningkatkan citra merek setiap produk yang diiklankan.

Citra merek smartphone Samsung mempengaruhi minat beli konsumen secara positif artinya, semakin tinggi citra merek suatu produk akan meningkatkan minat beli konsumen terhadap produk tersebut, begitu juga sebaliknya semakin rendah citra merek suatu produk maka akan menurunkan minat beli konsumen. penelitian ini menunjukkan bahwa citra merek smartphone Samsung mampu mencerminkan kualitas produk yang baik, kesadaran merek yang tinggi dan tingkat kesetiaan konsumen yang tinggi, sehingga meningkatkan minat beli konsumen terhadap merek smartphone Samsung. Hal ini berarti pengguna smartphone Samsung di kota Yogyakarta menggunakan citra merek Samsung untuk membentuk keyakinan tentang produk smartphone Samsung, sehingga menimbulkan minat untuk membeli smartphone Samsung. Dari hasil penelitian dapat disimpulkan bahwa citra merek yang tinggi untuk produk apapun dapat meningkatkan keinginan konsumen untuk membeli produk tersebut.

Kualitas pesan iklan produk smartphone Samsung dapat mempengaruhi minat beli secara positif artinya semakin baik kualitas pesan iklan maka semakin tinggi minat beli konsumen terhadap produk tersebut. Hal ini terjadi karena konsumen sebelum melakukan pembelian menyimpulkan dan menggeneralisasikan persepsi dan opini mereka terhadap kualitas pesan iklan produk tersebut. Jika kualitas pesan iklan menimbulkan persepsi positif maka konsumen akan mudah memahami deskripsi produk dengan baik. Pengguna smartphone Samsung di kota Yogyakarta sebelum melakukan pembelian, memahami deskripsi produk dari iklan yang terdapat di media sosial dan memberikan persepsi serta opini mereka tentang kualitas produk smartphone Samsung. Pesan iklan yang baik yang dipersepsikan oleh pengguna smartphone Samsung di kota 
Yogyakarta adalah pesan iklan yang mudah dipahami, mudah diingat, meyakinkan produk dapat diandalkan, dan memberikan informasi deskripsi produk yang jelas.

Citra merek memediasi secara parsial pengaruh kualitas pesan iklan produk smartphone Samsung terhadap minat beli. Semakin tinggi citra merek berarti semakin tinggi pula pengaruh antara kualitas pesan iklan dengan minat beli. Hal ini terjadi karena pengguna smartphone Samsung mempertimbangkan kualitas pesan iklan sebagai bahan pertimbangan untuk mengenal dan memahami produk sehingga mendorong minat beli produk smartphone Samsung. Jadi kualitas pesan iklan yang baik mampu meningkatkan citra merek, sehingga mendorong minat beli konsumen terhadap produk yang diiklankan.

Berdasarkan hasil penelitian, implikasi bagi manajer atau pimpinan perusahaan di negara Indonesia yang akan memasarkan produk ke negara asing, adalah perusahaan harus mampu membuat pesan iklan yang berkualitas dengan memperhatikan variabel mudah dipahami, mudah diingat, dapat dipercaya dan memberikan informasi deskripsi produk yang jelas. Pesan iklan yang berkualitas tersebut akan meningkatkan citra merek produk yang akan dipasarkan sehingga akan medorong minat beli konsumen luar negri terhadap produk yang diiklankan. Hasil penelitian belum dapat menggenalisir faktorfaktor yang mempengaruhi citra merek dan minat beli. Kualitas pesan iklan hanya salah satu faktor yang mendorong keinginan konsumen untuk membeli dan meningkatkan citra merek. Saran untuk penelitian berikutnya adalah menambahkan variabel-variabel lain yang dapat menggenalisir penjelasan peningkatan citra merek dan minat beli.

\section{REFERENSI}

Aaker, D. A. (2010). Building Strong Brands 1st ed. The Free Press: New York.

Aaker, D. A. and Robert Jacobson. (2011). "The value relevance of brand attitude in hightechnology markets", Journal of Marketing Research, Vol. XXXVIII, 485-493.

Bendixen, T. M. (2003). "Advertising Effect and Effectiveness", European Journal of Marketing, Vol. 27, No.10.

Dobni, D. and G.M. Zinkhan. (2010). "In Search of Brand Image: a Foundation Analysis", Advance in Consumer Research, Provo, pp. 110-119.

Durianto, Darmadi, Sugiarto dan Toni Sitinjak. (2001). Strategi Menaklukkan Pasar Melalui Riset Ekuitas dan Perilaku Merek, Jakarta: PT Gramedia Pustaka Utama.

Eva, S., Yoestini dan Rahma. (2007). "Analisis Pengaruh Kualitas Layanan dan Citra Merek terhadap Minat Beli dan Dampaknya pada Keputusan Pembelian”, Jurnal Sains Pemasaran Indonesia: 261-276.

Fazli, M., Mohd Sam dan Nor Hayati T. (2010). “Website Quality and Consumer Online Purchase Intention of Air Ticket", International Journal of Basic \& Applied Sciences IJBAS Vol: 9 No: 10 (2010).

Hoeffler, S. and Kevin Lane Keller. (2013). "The Marketing Advantages of Strong Brands", Brand Management, Vol. 10, No.6.

Keagan, W. J., Sandra E. Moriarty and Thomas R. Duncan. (2005). Marketing, Third Edition. Prentice Hall International Inc, Engelwood Cliffs, New Jersey.

Kinnear, T. C. and James R. Taylor. (2005). Riset Pemasaran, Dialihbahasakan oleh Yohanes Lamarto, Erlangga, Jakarta.

Kotler, P. (2013). Marketing, Planning, Implementing and Analizing, Milennium Edition, Prentice Hall.

Krisnan, H. S. and Dipankar Chakravarti. (2003). "Varieties of Brand Memory Induced by Advertising: Determinants, Measures, and Relationship", in Brand Equity and Advertising: Advertising Role in Building Strong Brands, David A. Aaker and Alexander L. Biel, Eds, Hilladale, NJ: Lawrence Erlbaum Associates. 
Low, G. S., Lamb Jr. and Charles W. (2010). "The Measurement and Dimensionality of Brand Associations", Journal of Product and Brand Management, Vol. 9 No. 6.

Mudiantono dan Bambang Agus Purnomo. (2005). "Analisis Pengaruh Segmentasi Pasar, Periklanan, Ekuitas Merek, dan Keunggulan Kompetitif terhadap Kinerja Pemasaran", Jurnal Sains Pemasaran Indonesia: 173-192.

Nicollino, P. F. (2014). The Complete Ideal Guide: Brand Management. Prenada, Jakarta.

Raharja, S. (2011). "Pengaruh Iklan terhadap Sikap yang Mendukung terhadap Produk", Jurnal Pemasaran Indonesia.

Russel, T. dan W. Ronald Lane K. (2006). Advertising Procedure, Prentice Hall, 13th, New Jersey.

Shih, T. Y. (2010). "Comparative Analysis of Marketing Strategies For Manufacturers' And Retailers' Brands", International Journal of Electronic Bussiness Management, Vol.8, No.1, pp. 56-67.

Stanton, W. J., Michael Etzel and Bruce J. Walker. (2004). Fundamentals of Marketing, New York: McGraw-Hill Inc.

Sukarno. (2005). "Pengaruh Iklan terhadap Sikap Konsumen", Jurnal Pemsaran Indonesia.

Tirtiroglu, E. dan Matt Elbeck. (2008). "Qualifying Purchase Intentions Using Queueing Theory". Journal of Applied Quantitative Methods. Vol : 3. No. 2.

Tseng, Ji-shou , Hung-Yu lin dan Lin Chien H. (2012)." A Study On The Effect of Enterprise Brand Strategy On Purchase Intention", International Journal of Organtizational Innovation, Vol. 4 No. 3.

Wells, W., Jhon Burnett and Sandra Moriarty. (2013). Advertising, Principles and Practice, sixth edition. New Jersey: Pearson Education, Inc.

www.teknojurnal.com

www.detiknet.com

www.tabloidpulsa.com

www.liputan6.com 